\title{
Fabrikasi dan Karakterisasi Briket Limbah Buah Pinus dengan Perekat Limbah Kulit Pohon Pinus
}

\author{
Murniati Linggi, Syahrul Ulum, Darmawati Darwis \\ Jurusan Fisika Fakultas Matematika dan Ilmu Pengetahuan \\ Alam Unversitas Tadulako \\ email: murnilinggi@gmail.com
}

\begin{abstract}
ABSTRAK
Penelitian tentang fabrikasi dan karakterisasi briket limbah buah pinus dengan perekat limbah kulit pohon pinus telah dilakukan. Penelitian ini bertujuan untuk mengetahui pengaruh konsentrasi limbah kulit pohon pinus sebagai perekat terhadap karakter briket tersebut. Proses pembuatan dimulai dengan melakukan karbonisasi limbah buah pinus dan penghalusan limbah kulit pohon pinus. Kedua bahan tersebut kemudian dicampur dan dicetak dengan metode cetak panas. Sampel briket yang dihasilkan dikarakterisasi untuk mengetahui kadar air, kadar abu, volatil matter, fixed carbon, nilai kalor, kuat tekan, lama penyalaan dan laju pembakaran. Hasil penelitian menunjukan sampel briket terbaik yaitu yang memiliki presentase campuran limbah kulit pohon pinus sebesar 37,5\% dengan hasil pengujian kadar air $6,85 \%$, kadar abu $3,99 \%$, volatil matter $38,55 \%$, fixed carbon $50,6 \%$, nilai kalor 6.138 $\mathrm{cal} / \mathrm{gr}$, laju pembakaran $0,14 \mathrm{gr} /$ detik,dan kuat tekan $526,1 \mathrm{kgf} / \mathrm{cm}^{2}$. Penambahan persentase perekat cenderung menambah kadar abu, fixed carbon, nilai kalor, kuat tekan, laju pembakaran dan cenderung menurunkan nilai kadar air, volatil matter, dan lama penyalaan. Hasil penelitian ini menunjukan bahwa limbah buah pinus dengan perekat limbah kulit pohon pinus layak digunakan sebagai bahan dalam karakterisasi biobriket
\end{abstract}

Kata Kunci: Limbah, Buah Pinus, Kulit Pohon Pinus, Briket

\begin{abstract}
Research on the fabrication and characterization of briquettes pine fruit waste with pine tree peel waste as adhesive has been carried out. This study aims to determine the effect of adding pine tree peel waste as an adhesive to the character of the briquette. The manufacturing process begins by carbonizing pine fruit waste and refining pine tree peel waste. The two ingredients were then mixed and printed with the hot print method. The resulting briquettes were characterized to determine water content, ash content, volatile matter, fixed carbon, calorific value, compressive strength, ignition time and combustion rate.The results showed that the best briquettes in this study were $37.5 \%$ mixture of pine tree waste with test result; water contet of $6.85 \%$, ash content of $3.99 \%$, volatile matter $38.55 \%$, fixed carbon $50,6 \%$, heating value of $6,138 \mathrm{cal} / \mathrm{gr}$, combustion rate of $0.14 \mathrm{gr} / \mathrm{sec}$, and compressive strength of $526.1 \mathrm{kgf} / \mathrm{cm}^{2}$. Addition of adhesive percentage tends to increase ash content, fixed carbon, heating value, compressive strength, combustion rate and tends to reduce the value moisture content, volatile matter, and ignition duration. The result of this study indicate that pine fruit waste with pine tree peel wasteis suitable to be used as material in biobriquette characterization.
\end{abstract}

Keywords: Waste, Pine Fruit, Pine Tree Peel, Briquettes 


\section{PENDAHULUAN}

Berkurangnya cadangan bahan bakar fosil seperti minyak dan gas bumi akan berdampak pada perekonomian kehidupan manusia. Bahan bakar fosil sudah menjadi bahan bakar yang biasa digunakan untuk memenuhi kebutuhan energi di dunia ini, sedangkan para penggunanya terkadang tidak memikirkan bahwa sumber energi tersebut tidak dapat diperbaharui. Untuk kembali mengisi cadangan minyak bumi diperlukan waktu yang sangat lama, sedangkan kebutuhan masyarakatan energi tidak bisa ditunda. Pada kondisi ini sangatlah diharapkan adanya energi sumber alternatif yang dapat menggantikan energi dari bahan-bahan fosil tumbuhan.

Salah satu sumber energi alternatif yang dapat digunakan yaitu energi biomassa. Biomassa adalah suatu limbah benda padat maupun cair yang bisa dimanfaatkan lagi sebagai sumber bahan bakar. Biomassa dikonversi menjadi energi dalam bentuk bahan bakar cair, gas, panas, dan listrik. Teknologi konversi biomassa menjadi bahan bakar padat, cair, dan gas, antara lain teknologi pirolis (bio-oil) (Ridhuan dan Suranto, 2016), esterifikasi (biodiesel) (Setiawati dan Edwar, 2012), teknologi fermentasi (bio-etanol) (Rosdiana, 2008), anaerobik digester (biogas) (Darmanto, dkk, 2012). Teknologi konversi biomassa menjadi energi panas yang kemudian dapat diubah menjadi energi mekanis dan listrik, antara lain, teknologi pembakaran dan gasifikasi.

Biomassa berasal dari bahan organik yang dihasilkan melalui proses fotosintetik, baik berupa produk maupun buangan. Biomassa dapat dibuat antara lain dari limbah pertanian, limbah hutan, tinja dan kotoran ternak. Salah satu limbah hutan yang berpotensi untuk dijadikan biomassa adalah limbah pohon pinus. Sumber energi ini relatif tidak mengandung unsur sulfur sehingga tidak menyebabkan polusi udara dan juga dapat meningkatkan efisiensi pemanfaatan sumber daya hutan dan pertanian (Syafi'i, 2003).

Pohon pinus adalah salah satu jenis tanaman yang banyak manfaatnya bagi kehidupan manusia. Manfaat dari pohon pinus antara lain digunakan untuk membuat kertas, getah pohon pinus untuk pengencer cat dan pembuatan korek api. Pohon pinus tumbuh dibeberapa wilayah di Indonesia dengan luas 144.950 ha (Perum Perhutani 2012). Salah satu wilayah di Indonesia yang memiliki hutan pinus yaitu di Sulawesi Tengah khususnya Kabupaten Poso, Kecamatan Pamona Puselemba, Dusun Kajuawu. Luas hutan pinus di daerah tersebut yaitu 400 ha. Sebagian besar masyarakat di daerah ini mengolah pohon pinus dengan mengambil getahnya melalui proses penyadapan. Dari proses penyadapan tersebut, banyak dihasilkan limbah berupa potonganpotongan kulit pohon pinus. Masyarakat didaerah tersebut menggunakan limbah potongan-potongan kulit kayu hasil penyadapan sebagai pengganti bahan bakar untuk menyalakan kayu yang akan dipakai untuk memasak. Selain limbah potonganpotongan kulit kayu terdapat juga limbah buah pinus yang tidak termanfaatkan.

Buah pinus dapat digunakan sebagai bahan bakar alternatif dalam bentuk briket (Suluh, 2017; Nofenda, 2014). Suluh dan Nofenda membuat briket dari buah pinus dengan bahan perekat dari kanji. Untuk lebih memanfaatkan limbah buah dan kulit pohon pinus maka pada penelitian ini akan dibuat dan dikarakterisasi briket buah pinus dengan perekat kulit pinus. Diharapkan hasil penelitian ini dapat membantu masyarakat untuk mengoptimalkan 
penggunaan limbah pohon pinus yang tidak terkelola dengan baik.

\section{Biomassa}

Biomassa meliputi limbah kayu, limbah pertanian/perkebunan/hutan, komponen organik dari industri dan rumah tangga. Energi biomassa dapat menjadi sumber energi alternatif pengganti bahan bakar fosil (minyak bumi) karena beberapa sifatnya yang menguntungkan yaitu sumber energi ini dapat dimanfaatkan secara lestari karena sifatnya yang dapat diperbaharui (renewable resources).

\section{Pohon Pinus (Pinus merkusii)}

Pinus merkusii (pinus) adalah salah satu tanaman monokotil yang mempunyai ciri khas dengan daunnya yang memipih seperti jarum dan berkelompok atau berupa sisik. Pinus memiliki strobilus jantan dan strobilus betina dalam satu pohon. Ukuran strobilus jantan lebih kecil dibandingkan dengan strobilus betina (berkayu), terletak aksilaris. Pohon berkayu (woods), strobilus bentuk konus. Tanaman Pinus merkusii secara morfologis, memiliki tujuh bagian, yaitu akar, batang, tangkai, daun, bunga, buah dan biji yang masing-masing berciri khas serta mempunyai fungsi yang berbeda dalam satu tumbuhan (Burtabutar, dkk, 1998). Di Indonesia, pinus mempunyai nama lain yaitu tusam. Jenis ini secara alami tersebar dari garis Bujur Timur 95 $30^{\circ}$ ' hingga $121^{\circ} 30^{\prime}$ dan garis Lintang Utara $22^{\circ}$ hingga garis Lintang Selatan $2^{\circ}$. Berdasarkan klasifikasi tumbuhan, Pinus merkusii termasuk dalam famili Pinaceae yaitu satu-satunya pinus yang penyebaran alaminya sampai di selatan khatulistiwa. Gambar 1 merupakan gambar limbah buah pinus dan limbah kulit pohon pinus.

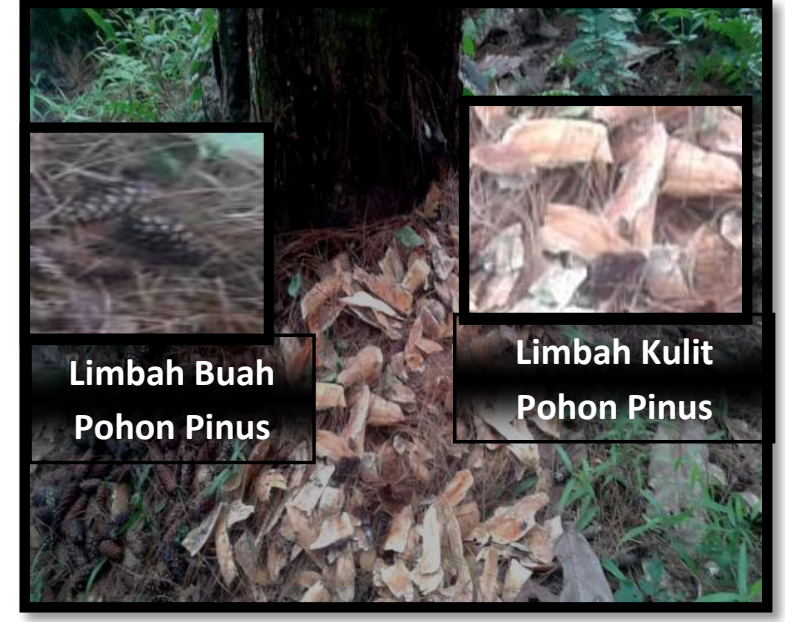

Gambar 1 Limbah buah dan kulit pohon pinus

\section{Briket}

Briket merupakan bahan bakar padat yang terbuat dari limbah organik, limbah pabrik maupun limbah perkotaan. Bahan bakar padat ini merupakan bahan bakar alternatif atau merupakan pengganti bahan bakar minyak yang paling murah dan dimungkinkan untuk dikembangkan dalam waktu yang relatif singkat mengingat teknologi dan peralatan yang digunakan relatif sederhana (Husada, 2008).

\section{Karakteristik Briket}

\section{Kalor}

Istilah kalor dipergunakan untuk menyatakan energi yang berpindah. Aliran kalor terjadi karena adanya perbedaan suhu, dan kalor mengalir dari suatu tempat yang suhunya tinggi ke tempat lain yang suhunya rendah. Kalor diberi simbol Q. Suatu sistem yang tidak terisolasi akan menyerap kalor dari lingkungannya jika suhu sistem lebih rendah dari suhu lingkungan, dan sebaliknya sistem akan melepaskan kalor ke lingkungannya jika suhu sistem lebih tinggi dari suhu lingkungan. 
2. Kadar air

Kadar air briket adalah perbandingan berat air yang terkandung dalam briket dengan berat kering briket tersebut setelah diovenkan. Peralatan yang digunakan dalam pengujian ini antara lain oven, cawan kedap udara, timbangan dan desikator (Kardianto, 2009).

\section{Kadar abu}

Abu atau disebut dengan bahan mineral yang terkandung dalam bahan bakar padat yang merupakan bahan yang tidak dapat terbakar setelah proses pembakaran. Abu adalah bahan yang tersisa apabila bahan bakar padat (kayu) dipanaskan hingga berat konstan (Earl, 1997). Kadar abu merupakan bagian yang tersisa dari hasil pembakaran dalam hal ini sisa pembakaran briket arang.

\section{Volatil matter}

Volatile Matter merupakan kandungan bahan yang dapat terbakar dan mudah membentuk gas. Kadar Volatile Matter yang tinggi dalam limbah pertanian mengindikasikan bahwa limbah pertanian mudah menyala dan terbakar walaupun pembakaran lebih cepat dan sulit dikontrol.

\section{Fixed carbon}

Fixed carbon merupakan bahan bakar padat yang tertinggal dalam tungku setelah bahan yang mudah menguap didistilasi. Kandungan utamanya adalah karbon tetapi juga mengandung hidrogen, oksigen, sulfur dan nitrogen yang tidak terbawa gas. Karbon terikat sebagai karbon (C) dalam arang selain fraksi abu, air dan zat mudah menguap.

\section{Kuat tekan}

Menurut Surdia dan Saito (1985), Pengujian kekuatan tekan dimaksudkan untuk mengetahui ketahanan polimer terhadap pembebanan. Pengujian ini juga dimaksudkan untuk mengetahui keelastisan suatu bahan. Pada pengujian ini apabila bahan diberi beban maka permukaan bawah akan memanjang dan terjadi pelengkunga. Besarnya pelengkungan pada titik tengah sampel dinamakan defleksi. Nilai kuat tekan dapat dihitung dengan menggunakan persamaan 1 .

$P=\frac{F_{\text {maks }}}{A}$

\section{Sifat - sifat penyalaan}

Sifat penyalaan ini diantaranya adalah mudah menyala, waktu cukup lama, tidak menimbulkan jelaga, asap sedikit dan cepat hilang serta nilai kalor yang cukup tinggi. Lama tidaknya menyala akan mempengaruhi kualitas dan efisiensi pembakaran. Semakin lama menyala. dengan nyala api konstan akan semakin baik (Hartoyo dan Roliadi, 1978).

\section{METODE PENELITIAN}

Pengambilan sampel buah dan kulit pohon pohon pinus dilakukan di Dusun Kajuawu, Kecamatan Pamona Puselemba, Kabupaten Poso. Sampel limbah buah pinus dikeringkan di bawah sinar matahari kemudian dikarbonisasi menggunakan tungku sederhana selama 15 menit. Sementara, limbah kulit kayu pohon pinus dikeringkan dengan dijemur dibawah sinar matahari, setelah itu dihaluskan menggunakan blender dan diayak dengan ayakan lolos 60 mesh. Pencampuran kayu dan arang dilakukan dengan persentase yang bervariasi. 
- Kayu=160 gr : Arang= 300 gr $=34,8 \%$

- Kayu=180 gr : Arang=300 gr =37,5\%

- Kayu=210 gr : Arang=300 gr = 41,2\%

- Kayu=240 gr : Arang= 300 gr = 44,4\%

Sebelum melakukan pembriketan, cetakan terlebih dahulu dipanaskan sehingga temperatur cetakan menjadi $120{ }^{\circ} \mathrm{C}$. Setelah temperatur catakan tercapai, bahan baku dimasukan ke dalam cetakan Kemudian bahan baku diberi tekanan sebesar 3 ton dengan waktu penahanan 1 menit.

Sampel biobriket yang telah dicetak kemudian dilakukan uji proksimat untuk mengetahui kadar air, kadar abu, vilatil matter, fixed carbon dan nilai kalor. uji nyala dilakukan menggunakan tungku sederhana dan stop watch, dan uji tekanan dilakukan menggunakan alat UTM tipe TN20MD.

\section{HASIL DAN PEMBAHASAN}

\section{Uji proksimat}

Tabel 1. Hasil uji proksimat

\begin{tabular}{|c|c|c|c|c|c|c|}
\hline \multirow[b]{2}{*}{$\begin{array}{l}\text { No. } \\
\text { Sampe } \\
1\end{array}$} & \multirow[b]{2}{*}{$\begin{array}{c}\text { Presentas } \\
\text { e perekat } \\
\quad(\%)\end{array}$} & \multicolumn{4}{|c|}{ Komposisi (\%) } & \multirow[b]{2}{*}{$\begin{array}{l}\text { Energi } \\
\text { (cal/gr } \\
\quad)\end{array}$} \\
\hline & & $\begin{array}{c}\text { Kadar } \\
\text { Air }\end{array}$ & $\begin{array}{l}\text { Kada } \\
\text { r Abu }\end{array}$ & $\begin{array}{c}\text { Volati } \\
\quad l \\
\text { Matte } \\
r\end{array}$ & $\begin{array}{c}\text { Fixed } \\
\text { Carbo } \\
n\end{array}$ & \\
\hline 1 & 34,8 & 7,11 & 3,57 & $\begin{array}{c}40,6 \\
4\end{array}$ & 48,68 & $\begin{array}{c}6.08 \\
8\end{array}$ \\
\hline 2 & 37,5 & 6,85 & 3,99 & $\begin{array}{c}38,5 \\
5\end{array}$ & 50,6 & $\begin{array}{c}6.13 \\
8\end{array}$ \\
\hline 3 & 41,2 & 7,29 & 3,04 & $\begin{array}{c}35,5 \\
4\end{array}$ & 54,14 & $\begin{array}{c}6.18 \\
8\end{array}$ \\
\hline 4 & 44,4 & 6,52 & 4,96 & $\begin{array}{c}33,2 \\
2\end{array}$ & 55,3 & $\begin{array}{c}6.17 \\
8\end{array}$ \\
\hline
\end{tabular}

a. Kadar air dan kadar abu

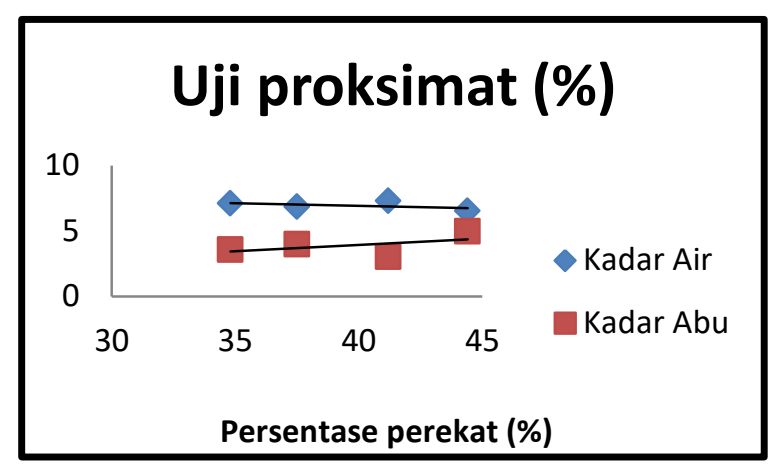

Gambar 2. Grafik hasil uji kadar air dan kadar abu

Berdasarkan Gambar 2 terlihat bahwa kadar air dari semua sampel memenuhi standar SNI yaitu dibawah 8\%. Gambar 2 juga memperlihatkan trendline pengaruh penambahan limbah kulit pohon pinus terhadap nilai kadar air. Tampak bahwa semakin banyak campuran limbah kulit kayu pohon pinus, maka nilai dari kadar air semakin menurun. Hal ini karena kadar arang semakin berkurang, di mana arang mudah menyerap molekul air $\mathrm{H}_{2} \mathrm{O}$ (Berlianto, 2018) sehingga kadar air semakin berkurang.

Selain itu pada Gambar 2 tampak bahwa nilai kadar abu dari semua sampel telah memenuhi SNI, dengan nilai dibawah $10 \%$. Trendline dari kadar abu pada Gambar 2 memperlihatkan semakin banyak campuran limbah kulit pohon pinus, maka nilai kadar abu semakin tinggi. Semakin bertambahnya kadar abu disebabkan oleh semakin banyaknya campuran kulit kayu pohon pinus yang menjadi abu sehingga tidak banyak yang menguap sebagai gas (Asip, 2007) 


\section{b. Kadar abu dan Fixed carbon}

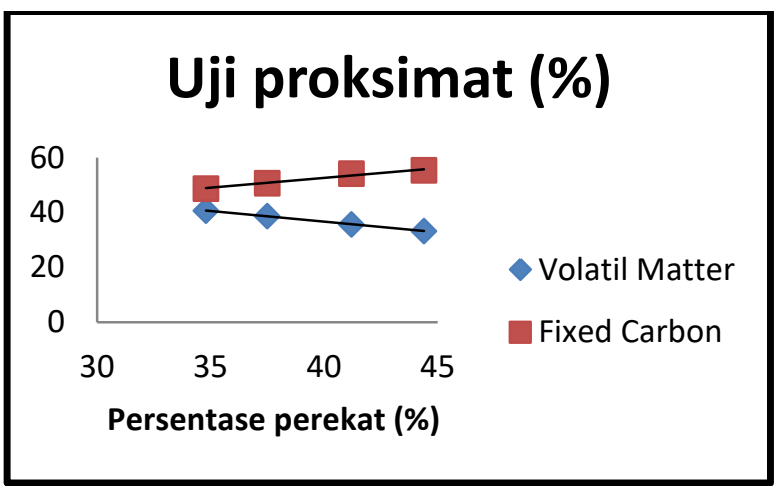

Gambar 3 Grafik hasil uji volatilmatter dan fixed carbon

Pada Gambar 3 terlihat bahwa volatil matter semua sampel tidak memenuhi SNI, karena berada diatas $30 \%$. Tampak pada Gambar 3 trendline pengaruh penambahan limbah kulit pohon pinus terhadap volatil matter. Semakin banyak campuran limbah kulit pohon pinus, maka nilai volatil matter semakin menurun. Hal ini dikarenakan semakin banyak campuran kulit kayu pohon pinus maka arang semakin sedikit, yang dimana arang berkonstribusi menguap sebagai gas (Asip, 2017). Sehingga semakin berkurangnya arang maka volatilil matter semakin berkurang

Berdasarkan Gambar 3 fixed carbon dari semua sampel hanya campuran $37,5 \%$ yang memenuhi SNI karena berada pada range 4952\%. Gambar 3 memperlihatkan trendline pengaruh penambahan limbah kulit pohon pinus terhadap nilai fixed carbon yang semakin meningkat. Hal ini sesuai dengan nilai kadar abu pada Gambar 2 dimana semakin bertambahnya kadar abu disebabkan oleh semakin banyaknya campuran kulit kayu pohon pinus yang menjadi abu sehingga tidak banyak yang menguap sebagai gas (Asip, 2007).

\section{c. Nilai Kalor}

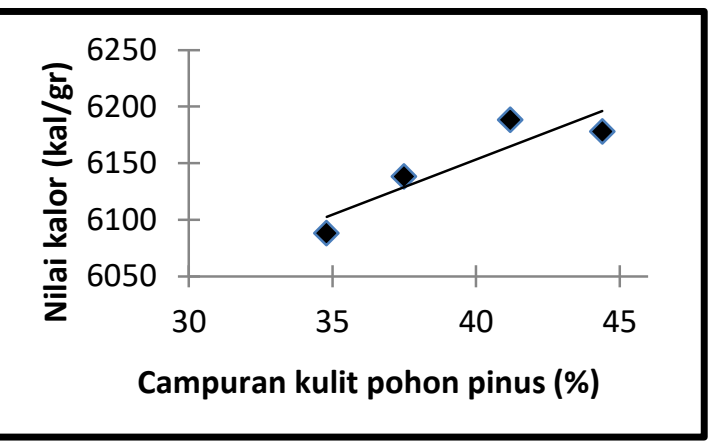

Gambar 4 Grafik hasil uji nilai kalor

Pada Gambar 4 tampak bahwa nilai kalor dari semua sampel telah memenuhi standar SNI, yaitu diatas $5.600 \mathrm{kal} / \mathrm{gr}$. Trendline nilai kalor pada Gambar 4 memperlihatkan pengaruh penambahan limbah kulit kayu tehadap nilai kalor. Tampak bahwa semakin banyak campuran limbah kulit pohon pinus maka nilai kalor semakin tinggi. Menurut Hendra dan Wiarni nilai kalor dipengaruhi oleh kadar ficed carbn dimana semakin tinggi fived carbon, nilai kalor semakin tinggi (Hendra dan Wiarni, 2003). Berdasarkan trend line fixed carbon pada Gambar 3, nilai Fixed carbon semakin meningkat sehingga nilai kalor akan meningkat.

\section{Uji Nyala}

Tabel 2 Hasil uji nyala

\begin{tabular}{|c|c|c|c|}
\hline No & $\begin{array}{c}\text { Presentase } \\
\text { perekat (\%) }\end{array}$ & $\begin{array}{c}\text { Lama } \\
\text { penyalaan } \\
\text { sampai } \\
\text { jadi abu } \\
\text { (detik) }\end{array}$ & $\begin{array}{c}\text { Kecapatan } \\
\text { pembakaran } \\
\text { (gr/detik) }\end{array}$ \\
\hline 1 & 34,8 & 52,15 & 0,13 \\
\hline 2 & 37,5 & 48,55 & 0,14 \\
\hline 3 & 41,2 & 43,47 & 0,17 \\
\hline 4 & 44,4 & 39,07 & 0,1 \\
\hline
\end{tabular}




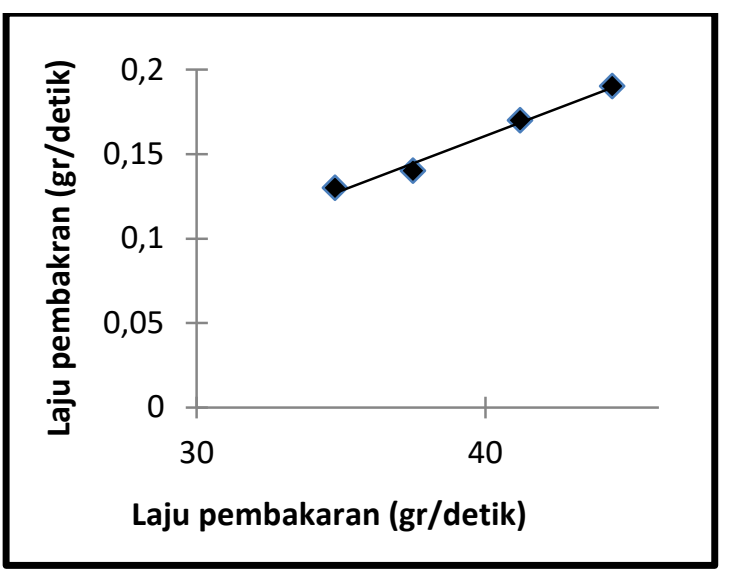

Gambar 5. Grafik hasil uji laju pembakaran

Berdasarkan Gambar 5 memperlihatkan trendline pengaruh penambahan limbah kulit pohon pinus terhadap laju pembakaran. Tampak bahwa semakin banyak campuran limbah kulit pohon pinus maka nilai laju pembakaran semakin tinggi. Hal ini dikarenakan kulit pohon pinus yang mengandung lignin, sehingga mudah terbakar (Saputro D Danang, dan Widayat, Widi 2016).

\section{Uji Kuat Tekan}

Tabel 3 Hasil uji kuat tekan

\begin{tabular}{|c|c|c|c|}
\hline No & $\begin{array}{c}\text { Presentas } \\
\text { e perekat } \\
(\%)\end{array}$ & $\begin{array}{c}\text { Gaya } \\
(\mathrm{N})\end{array}$ & $\begin{array}{c}\text { Tekanan } \\
\left(\mathrm{kgf} / \mathrm{cm}^{2}\right)\end{array}$ \\
\hline 1 & 34,8 & $\begin{array}{c}27.82 \\
0\end{array}$ & 400,7 \\
\hline 2 & 37,5 & $\begin{array}{c}36.47 \\
0\end{array}$ & 526,1 \\
\hline 3 & 41,2 & $\begin{array}{c}41.29 \\
0\end{array}$ & 595,5 \\
\hline 4 & 44,4 & $\begin{array}{c}50.93 \\
0\end{array}$ & 735,2 \\
\hline & & & \\
\hline
\end{tabular}

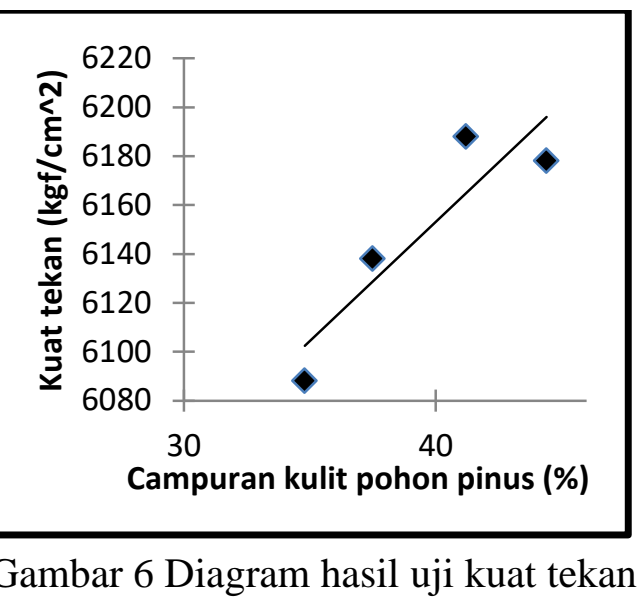

Gambar 6 terlihat bahwa hasil dari kuat tekan semua sampel memenuhi standar SNI, yaitu diatas $50 \mathrm{kgf} / \mathrm{cm}^{2}$. Gambar 6 juga memperlihatkan trendline pengaruh penambahan limbah kulit pohon pinus terhadap kuat tekan. Tampak bahwa semakin banyak kulit kayu pohon pinus, maka nilai kuat tekan semakin tinggi. Hal ini menunjukan semakin kuatnya ikatan partikel penyusun pada briket, sehingga ketahanan pada briket tersebut tidak menjadi mudah rapuh dan pecah.

\section{Rekomendasi SNI}

Tabel 4 Persentase kesesuaian SNI

\begin{tabular}{|c|c|c|c|c|c|}
\hline \multirow{2}{*}{ Karakteristik } & \multirow{2}{*}{$\begin{array}{c}\text { Standar } \\
\text { mutu } \\
\text { briket } \\
\text { (SNI) }\end{array}$} & \multicolumn{4}{|c|}{ Hasil persentase campuran perekat } \\
\hline & & 34,8 & 37,5 & 41,2 & 44,4 \\
\hline Kadar air (\%) & 8 & $\sqrt{ }$ & $\sqrt{ }$ & $\sqrt{ }$ & $\sqrt{ }$ \\
\hline $\begin{array}{c}\text { Kadar abu } \\
(\%)\end{array}$ & 10 & $\sqrt{ }$ & $\sqrt{ }$ & $\sqrt{ }$ & $\sqrt{ }$ \\
\hline $\begin{array}{c}\text { Volatil } \\
\text { matter }(\%)\end{array}$ & 30 & & & & \\
\hline $\begin{array}{c}\text { Fixed carbon } \\
(\%)\end{array}$ & $49-52$ & & $\sqrt{ }$ & & \\
\hline $\begin{array}{c}\text { Nilai kalor } \\
\text { (kal/gr) }\end{array}$ & 5600 & $\sqrt{ }$ & $\sqrt{ }$ & $\sqrt{ }$ & $\sqrt{ }$ \\
\hline $\begin{array}{l}\text { Kuat tekan } \\
\left(\mathrm{kgf} / \mathrm{cm}^{2}\right)\end{array}$ & $\min 50$ & $\sqrt{ }$ & $\sqrt{ }$ & $\sqrt{ }$ & $\sqrt{ }$ \\
\hline $\begin{array}{r}\text { Persentase ke } \\
\text { dengan }\end{array}$ & $\begin{array}{l}\text { esuaian } \\
\text { NI }\end{array}$ & $66,60 \%$ & $83,30 \%$ & $66,60 \%$ & $66,60 \%$ \\
\hline
\end{tabular}




\section{DAFTAR PUSTAKA}

Dari Tabel 4 menunjukan bahwa persentase perekat dengan campuran kulit kayu 37,5\% adalah campuran variasi perekat terbaik yang hampir semuanya memenuhi SNI. Meskipun volatil matter tidak memenuhi SNI. Sampel dengan persentase campuran perekat $37,5 \%$ memiliki nilai kadar air 6,85\%, kadar abu $3,99 \%$, volatil matter $38,55 \%$, Fixed carbon $50,6 \%$, nilai kalor $6.138 \mathrm{cal} / \mathrm{gr}$ dan kuat tekan $526,1 \mathrm{kgf} / \mathrm{cm}^{2}$.

\section{KESIMPULAN DAN SARAN}

Berdasarkan dari hasil penelitian yang telah dilakukan dapat disimpulkan bahwa:

1. Briket limbah buah pinus dengan perekat limbah kulit pohon pinus yang terbaik pada penelitian ini adalah sampel 2 yang memiliki persentase limbah kulit pohon pinus sebanyak 37,5\% karena memiliki lebih banyak karakter yang memenuhi SNI, yaitu kadar air 6,85\%, kadar abu $3,99 \%$, volatil matter $38,55 \%$, fixed carbon 50,6\%, nilai kalor $6138 \mathrm{kal} / \mathrm{gr}$, laju pembakaran $0,14 \mathrm{gr} /$ detik dan kuat takan $526,1 \mathrm{kgf} / \mathrm{cm}^{2}$.

2. Penambahan jumlah perekat limbah kulit pohon pinus akan:

- Cenderung menambah nilai kadar abu, fixed carbon, nilai kalor, kuat tekan dan laju pembakaran.

- Cenderung menurunkan nilai kadar air, volatil matter, dan lama penyalaan.

\section{Saran}

Untuk penelitian selanjutnya diharapkan untuk memperbanyak sampel untuk setiap jenis sampel saat melakukan uji proksimat agar hasil yang diperoleh lebih akurat.
Asip. F. 2017. Pengaruh Temperatur Karbonisasi dan Komposisi Arang Terhadap Kualitas Biobriket dari Campuran Cangkang Biji karet dan Kulit Kacang Tanah. Jurusan Teknik Kimia Fakultas Teknik Universitas Sriwijaya.

Berlianto. O. 2018. Uji Efektifitas Arang Kayu Sebagai Media Penyerap Kelembaban (RH) Pada Wadah Simpan Benih Padi (Oryza Sativa L). Lampung: Jurusan Teknik Pertanian Fakultas Pertanian Universitas Lampung

Butarbutar, T. R. M. S. Harahap, dan P. Murdiana. 1998. Evaluasi Pertumbuhan Tanaman Pinus merkusii di Aceh

Saputro D. Danang dan Widayat Widi. 2016. Karakterisasi Limbah Pengolahan Kayu Sengon sebagai Bahan Bakar alternatif. Semarang: Jurusan Teknik Mesin fakultas Teknik Universitas Negeri Semarang.

Darmanto, Ardyanto. dkk. 2012. Pengaruh kondisi temperatur mesophilic () dan Thermophilic () Anaerob digester Kotoran Kuda terhadap produksi biogas. Malang: Jurusan teknik mesin Fakultas Teknik fakultas brawijaya Malang.

Earl, D. E., 1997. A Report on Corcoal, Andre Meyer Research Fellow.FAO. Rome.

Hartoyo, A., dan Roliadi, H., 1978, Percobaan Pembuatan Briket Arang dari Lima Jenis Kayu, Laporan Penelitian Hasil Hutan Bogor.

Hendra, D. dan I. Winarni. 2003. Sifat fisis dan kimia briket arang campuran limbah kayu gergajian dan sebetan kayu. Buletin Penelitian Hasil Hutan. 21(3) : 211 - 226. Pusat Penelitian dan Pengembangan Hasil Hutan, Bogor. 
Husada, T. I. 2008. Arang Briket Tongkol Jagung sebagai Energi Alternatif, Laporan penelitian Program Penelitian Inovasi Mahasiswa Provinsi Jawa Tengah, Universitas Negeri Semarang, Semarang.

Kardianto, P., 2009. Pengaruh Variasi Jumlah Campuran Perekat terhadap Karakteristik Arang Briket Batang Jagung. Skripsi. Universitas Negeri Semarang. Semarang.

Novenda. T. 2014. Pemanfaatan Konus Pinus Merkusii Sebagai Bahan Bakar Alternatif Bagi Masyarakat Sekitar Hutan. Karya Ilmiah. Jawa Tengah

Perhutani, Perum. 2002. Rencana Pengaturan Kelestarian Hutan Kelas Perusahaan Jati KPH Randu blatung Jangka Perusahaan 1 Januari 2003 s/d 31 Desember 2013.

Ridhuan, k. dan Suranto, J. 2016. Perbandigan pembakaran pirolisis dan karbonisasi pada biomassa kulit dirian terhadap nilai kalori Vol. 5. lampung: Universitas muhammadiyah metro.

Rosdiana. 2008. Studi kinetika teknologi fermentasi etanol dengan pendekatan "Minimal Residual Substrat". Palembang: Jurusan Teknik Kimia fakultas Teknik Universitas Sriwijaya.

Setiawati, E. Edwar, F. 2012. Teknologi Pengolahan Biodisel dari Minyak Goreng Bekas dengan Teknik Mikrofiltrasi dan Transesterifikasi sebagai Alternatif Bahan Bakar Mesin Diesel. Banjarbaru: Balai Riset dan Standardisasi Industri Banjarbaru.

Suluh, S. 2017. Studi Eksperimen Limbah Buah Pinus Sebagai Sumber Energi Alternatif Ditinjau dari Variasi Butiran. Teknik Mesin. Universitas Kristen Indonesia Toraja.
Surdia, T. dan Saito, S. (1985). Pengetahuan bahan teknik. Cetakan Pertama, PT: Pradnya Paramita, Jakarta.

Syafi'i, W. 2003. Hutan Sumber Energi Masa Depan. www.kompas.co.id. Harian kompas 15 april 2003. www.adobe.com/rdrmessage_CPDF04_ ENUTeknologi Pengolahan Briket di Jepang 